\title{
POTENSI SENYAWA BULLATALISIN SEBAGAI INHIBITOR PROTEIN LEUKOTRIEN A4 HIDROLASE PADA KANKER KOLON SECARA IN SILICO
}

\author{
Harry Noviardi ${ }^{*}$, Fachrurrazie $^{2}$ \\ ${ }^{1)}$ Program Studi Farmasi, Sekolah Tinggi Teknologi Industri dan Farmasi Bogor \\ ${ }^{2)}$ Program Keahlian Analisis Kimia Diploma, Institut Pertanian Bogor \\ Email:harry.noviardi@gmail.com
}

\begin{abstract}
ABSTRAK
Kanker kolon merupakan jenis kanker yang dapat menyebabkan kematian. Salah satu penyebabnya adalah pertumbuhan Leukotrien A4 hidrolase yang tidak terkontrol. Leukotrien A4 hidrolase dapat dijadikan target terapi dalam menekan pertumbuhan sel kanker. Bullatalisin merupakan senyawa turunan asetogenin yang memiliki potensi inhibitor terhadap Leukotrien A4 hidrolase. Penelitian ini bertujuan menentukan potensi Bullatalisin sebagai inhibitor secara in silico berdasarkan energi bebas Gibbs $(\Delta G)$, tetapan inhibisi, interaksi ikatan hidrogen serta Root Mean Deviation Square (RMSD). Penelitian dilakukan secara komputasi menggunakan metode molecular docking.Berdasarkan pada hasil analisis visualisasi interaksi docking, menunjukkan adanyainteraksi ikatan antara Bullatalisin dan residu asam amino dari kantung aktif Leukotrien A4 hidrolase. Selain itu nilai energi bebas Gibbs, tetapan inhibisi dan RMSD dari Bullatalisin tidak berbeda secara signifikan dibandingkan dengan ligan standar. Oleh karena itu, Bullatalisin diprediksi berpotensi sebagai inhibitor Leukotrien A4 hidrolase.
\end{abstract}

Kata kunci: bullatalisin, docking, in silico, kanker kolon, leukotrien A4 hidrolase

\section{THE POTENCY OF BULLATALICIN AS AN INHIBITOR OF LEUKOTRIENE A4 HYDROLASE PROTEIN IN COLON CANCER BY IN SILICO STUDY}

\begin{abstract}
Colon cancer was a cancer type that could be death. One of the reason was the growth Leukotriene A4 hydrolase that were out of control. Leukotriene A4 hydrolase might be used as a therapeutic target in suppressing the growth of cancer cells. Bullatalicin asetogenin derivative was a compound that has the potential to inhibit Leukotriene A4 hydrolase. This study aims to determine the potential Bullatalicin as inhibitors in silico based on the Gibbs free energy $(\Delta G)$, inhibition constant, hydrogen bonding interactions and Root Mean Deviation Square (RMSD). The computationally study using molecular docking method. The results of docking interaction visualization, shows the bonding interactions between Bullatalicin and amino acid residues of the catalytic domain. In addition the value of Gibbs free energy, constant inhibition of Bullatalicin and RMSD not significantly different than the standard ligand. Therefore, Bullatalicin could be predicted as potential Leukotriene A4 hydrolase inhibitor.
\end{abstract}

Keywords: Bullatalicin, colon cancer, docking, in silico, leukotriene A4 hydrolase

\section{PENDAHULUAN}

Leukotrien A4 hidrolase (LTA4H) adalah enzim yang berperan sebagai epoksida hidrolase dan aminopeptidase. Enzim LTA4H tersebut dapat mengkatalisis dari hidrolisis Leukotrien A4 epoksida membentuk leukotrien B4, yang memiliki peran dalam aktivasi inflamasi sel dan kanker pada manusia (Chen et al., 2004 \& Stsiapanava et $a l ., 2014)$. Selain itu LTA4H diekspresikan secara berlebih pada sel kanker dibandingkan dengan sel normal termasuk sel kanker kolon 
(Chulet al., 2009). Hal ini berdasarkan pada penelitian Jeong et al. (2009) secara in vitro, menunjukkan enzim LTA4H dapat meningkatkan pertumbuhan sel kanker kolon HCT116. Inhibisi senyawa kandidat obat (lead compound) diharapkan dapat menurunkan fungsi enzim Leukotrien A4 hidrolase sehingga dapat menekan perkembangan sel kanker (Chen et al., 2003 \& Arguelloet al., 2006). Affinitas aminopeptidase LTA4H tertinggi terhadap substrat tripeptida terletak pada N-terminal (Orning et al., 1994\& Tholander et al., 2008). Pada penelitian Stsiapanavaet al. (2014), menunjukkan bahwa ikatan subtrat analog Pro-Gly-Pro pada sisi kantung aktif LTA4H, dapat mempengaruhi kinerja enzim tersebut sebagai epoksida hidrolase.

Kantung aktif dari LTA4H tersusun dari beberapa asam amino, yaitu Gln 134, Gln 136, Tyr 267, Gly 268, Gly 269, Met 270, Glu 271, Val 292, Glu 296, Trp 311, Phe 314, Trp 315, Val 322, Phe 362, Val 367, Leu 369, Ile 372, Pro 374, Asp 375, Ala 377, Tyr 378, Tyr 383, Lys 565, Arg 563 (Marjoleinet al., 2001). Inhibisi LTA4H dengan cara menutup sisi lubang pada kantung aktif dengan inhibitor dapat menghambat pembetukkan leukotrien B4, sehingga proses inflamasi terhambat (Haeggström et al., 2011). Oleh karena itu, LTA4H dapat menjadi target dari terapi pengobatan kanker (Chen et al., 2004).

Bullatalisin merupakan senyawa turunan asetogenin, yang memiliki dua cincin tetrahidrofuran dan diisolasi dari kulit Annona bullata. Senyawa ini bersifat selektif terhadap apoptosis sel kanker dan memiliki aktivitas sitotoksik dengan nilai $\mathrm{ED}_{50}$ kurang dari $10^{-7}$ $\mathrm{mcg} / \mathrm{mL}$ (Yu et al., 1989\& Liang et al., 2009). Selain itu Bullatalisin memiliki bioaktifitas terhadap antitumor dalam penghambatan pembentukkan kompleks mitokondria dan NADH oksidase dari membran sel tumor (Okunet al., 1999). Bullatalisin juga dapat menurunkan konsentrasi intracellular cyclic AMP (cAMP) and cyclic GMP (cGMP) sehingga dapat menginduksi apoptosis dari sel tumor (Chiuet al., 2003). Oleh karena itu, Bullatalisin diharapkan memiliki potensi untuk menjadi senyawa inhibitor terhadap LTA4H.

Analisis model interaksi antara kristal LTA4H dan senyawa inhibitor secara in silico dapat membantu dalam pengembangan obat berbasis struktur (Thunnissen et al., 2001). Metode molecular docking merupakan langkah awal dalam pengembangan obat berbasis struktur, yang memiliki kelebihan, yaitu sangat cepat, hemat biaya dan akurat. Pada penelitian ini dilakukan secara in silico menggunakan metode molecular docking. Metode molecular docking merupakan metode utama komputasi dalam proses pencarian dan pengembangan obat (Rester, 2008). Prinsip molecular docking adalah dengan mengikatkan subtrat atau ligan pada enzim sehingga membentuk konformasi molekul kompleks. Selain itu docking juga mempertimbangkan aspek kestabilan konformasi antara enzim dan ligan yang terbentuk tersebut (Sousa et al., 2006). Secara umum docking dapat dilakukan secara rigid body docking dan fleksibel docking. Metode fleksibel docking lebih baik dibandingkan dengan rigid docking, karena pada docking secara rigid, ligan mengalami rotasi dan translasi yang terbatas. Docking secara fleksibel merupakan metode yang umum dilakukan karena ikatan kompleks dan fleksibilitas konformasi antara ligan dan protein menjadi parameter utama dalam penilaian afinitas docking (Sousa et al., 2006 \&Gilson et al., 2007).

Docking pada penelitian ini menggunakan program AutoDock. Prinsip dari program AutoDock adalah mengevaluasi dari energi bebas, torsional bebas dari konformasi ikatan yang terbentuk antara enzim dan ligan berdasarkan energi forcefield pada algoritma, serta kekuatan kompleks ligan-protein yang terbentuk secara kuantitatif dengan melihat nilai tetapan inhibisi. Nilai skor docking yang semakin negatif dan kecil menunjukkan konformasi yang terbentuk antara ligan dan enzim semakin stabil (Idrees et al,. 2014).

Akurasi hasil docking perlu dilakukan untuk mengukur ketepatan algoritma dari program untuk menentukan posisi dari 
konformasi antara enzim dan ligan. Parameter dari nilai akurasi tersebut adalah Root Mean Deviation Square (RMSD) (Hevener et al., 2009). RMSD ditentukan dengan membandingkan antara posisi atomatom ligan secara ekperimental dan posisi berdasarkan pada prediksi algoritma. Fleksibelitas dari ligan tersebut dapat mempengaruhi ketepatan posisi kompleks yang terbentuk (Sousa et al., 2006). Hasil Docking yang baik jika memiliki nilai RMSD kurang dari $2 \AA$ (Purnomo, 2013 \& Santoyo et al., 2013).

Penelitian ini bertujuan menentukan potensi Bullatalisin sebagai inhibitor LTA4H secara in silico berdasarkan pada energi bebas Gibbs $(\Delta G)$, tetapan inhibisi, interaksi ikatan hidrogen antara protein dan ligan serta Root Mean Deviation Square (RMSD). Penelitian dilakukan secara fleksibel docking dengan menggunakan program AutoDock.

\section{METODE PENELITIAN Bahan}

Perangkat lunak AutoDock Vina, AutoDock Tools 1.5.6., Open Babel 2.3.6., Pymol, YASARA. Program database online yang digunakan PDB (Protein Data Bank)

\begin{abstract}
Alat
Seperangkat komputer dengan chip processorCore ${ }^{\mathrm{TM}}$ i5-3230M2 Cores, 4 Threads@2.6GHz,4.00 GB DDR31600 MHzrandom access memory,2GB DDR3 Radeon HD 8670M video graphics array, ditunjang dengan akses internet untuk mengunduh data-data protein.
\end{abstract}

\section{Cara Kerja}

\section{Preparasi Ligan dan Protein}

Ligan yang digunakan pada penelitian ini dirancang dalam bentuk 3 dimensi dengan menggunakan ACD Labs dengan format .mdlmol. Setelah itu format ligan dirubah dalam bentuk pdb dengan menggunakan Open Babel (Boyle et al., 2011). Ligan yang digunakan adalah Bullatalisin dan ligan standar N-[3-(4-benzilfenoksi)propil]-Nmetil-beta-alanina (Niegowski et al., 2012).
ProteinLeukotrien A4 hidrolase ditelusuri pada situs Protein Data Bank (http://www.rscb.org/pdb/) dengan menggunakan komputer yang terhubung dengan internet. Protein diunduh dalam format $\mathrm{pdb}$. Kode protein yang digunakan adalah 3U9W, yang memiliki tingkat resolusi $1.25 \AA$ Á.

File protein dan ligan yang telah diunduh, dibuka dengan menggunakan AutoDock Tools1.5.6. dalam format .pdbkemudian dilakukan preparasi ligan dan protein pada AutoDock Tool. Setelah itu file disimpan dalam bentuk .pdbqt (Protein Data Bank, Partial Charge (Q), \& Atom Type (T))

Ukuran grid ditentukan pada protein dengan nilai sumbu $x, y$, dan $z$, dengan satuan angstrom $(\AA)$. Grid dibuat sebesar mungkin sampai tepat menutupi seluruh kantung aktif permukaan protein. Format file penyimpan grid disimpan dalam bentuk grid.gpf.

\section{Docking}

Preparasi file docking dilakukan optimasi geometri dan energi bebas $\operatorname{Gibbs}(\Delta \mathrm{G})$ dari struktur 3 dimensi ligan dengan menggunakan AutoDock1.5.6. Algoritma yang digunakan adalah Lamarckian Genetic. Proses docking dilakukan dengan AutoDock dan AutoDock Vina, dengan memasukkan nilai parameter Autogrid (Trottet al., 2010). File tersebut kemudian disimpan dalam bentuk kompleks untuk divisualisasikan menggunakan Pymol.

\section{Analisis Docking \\ PenentuanNilai Energi Bebas Ikatan}

Energi bebas ikatan hasil docking dilihat pada output dalam AutoDock Tools1.5.6. Konformasi kompleks proteinligan yang dipilih adalah kompleks yang memiliki nilai energi bebas ikatan terkecil untuk kemudian dilakukan analisis lebih lanjut.

\section{Penentuan Ikatan Hidrogen dan Kontak Residu}

Ikatan hidrogen dan kontak residu yang terjadi pada konformasikompleksproteinligan terbaik dari hasil docking 
kemudiandiidentifikasikan dan dianalisis dalam media 3 dimensi dengan menggunakan Pymol. Format file yang digunakan untuk identifikasi dan analisis adalah .pdb dan .pdbqt.

\section{Penentuan RMSD}

Evaluasi hasil docking dilakukan dengan menggunakan hasil docking dari ligan standar dan protein. Konformasi kompleks protein-ligan yang memiliki nilai energi bebas ikatan terendah ditentukan nilai RMSD sebanyak 10 kali ulangan dengan menggunakan program YASARA (Purnomo, 2013).

\section{HASIL DAN PEMBAHASAN VisualisasiKantung Aktif Protein dan Ligan}

Struktur kristal Leukotrien A4 Hidrolase yang digunakan pada penelitian ini dengan kode 3U9W memiliki tingkat resolusi $1.25 \AA ̊$ (Niegowski et al., 2012). Kristal tersusun dari asam amino penyusun proteinLeukotrien A4 Hidrolase yang terdiri atas 608 asam amino. Protein LTA4H tersusun menjadi 3 bagian folding, yaitu $\mathrm{N}$ terminal, kantung aktif, dan C-terminal, yang membentuk flat triangular dengan dimensi $78.08 \times 86.80 \times 99.14 \AA$. Residu asam amino penyusun protein LTA4H dapat dilihat pada Gambar 1. Pada N-terminal LTA4H terdapat daerah kantung aktif (Thunnissen et al., 2001). Residu kantung aktif terbentuk pada daerah asam amino 130-385 dan 560-565 (Marjolein et al., 2001).

\section{Docking}

Docking terhadap protein Leukotrien A4 Hidrolase dilakukan pada daerah kantung aktif. Penentuan daerah kantung aktif dilakukan dengan autogrid yang terdapat pada AutoDock Tools 1.5.6. Grid merupakan daerah tempat terjadinya interaksi ligan dengan kantung aktif protein pada proses docking, yang berbentuk kubus atau balok dengan sebuah titik pusat $x, y, z$ dan dimensi $x, y, z$. Nilai grid box yang diperoleh pada penelitian ini, yaitu x:29.679, y:1.546, $\mathrm{z}: 1.893$ dengan ukuran box $60 \times 60 \times 60 \AA$ (Gambar 2a). Nilai grid box tersebut ditentukan berdasarkan pada posisi letak senyawa ligan standar pada protein 3U9W yang terdapat pada file Protein Data Bank (PDB). Algoritma docking Lamarckian Genetic pada AutoDock Tools akan menampilkan total konformasi terbaik sebanyak 10 interaksi ligan (Morriset al., 1998). File protein diolah menggunakan AutoDock Tools, kemudian protein dibersihkan dari molekul-molekul air dan dilakukan penambahan hidrogen. Penambahan atom hidrogen dilakukan karena terdapat kemungkinan hilangnya atom hidrogen pada saat kristalisasi yang dapat mempengaruhi interaksi (Seeligeret al., 2010). Visualisasi 3 dimensi lubang kantung aktif protein LTA4H dapat dilihat pada Gambar 2b. Lubang kantung aktif terletak pada daerah domain katalitik $\mathrm{N}$-terminal yang bersifat hidrofobik.

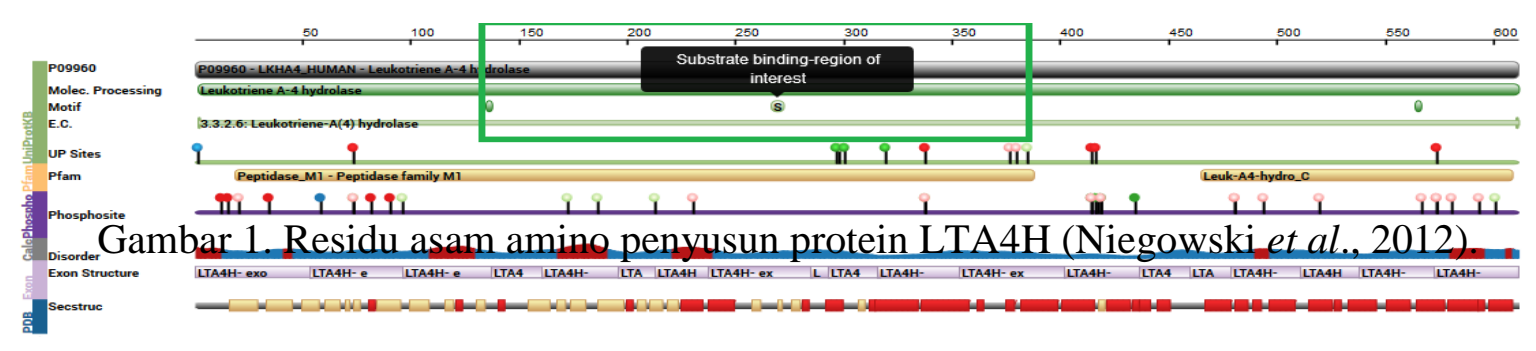




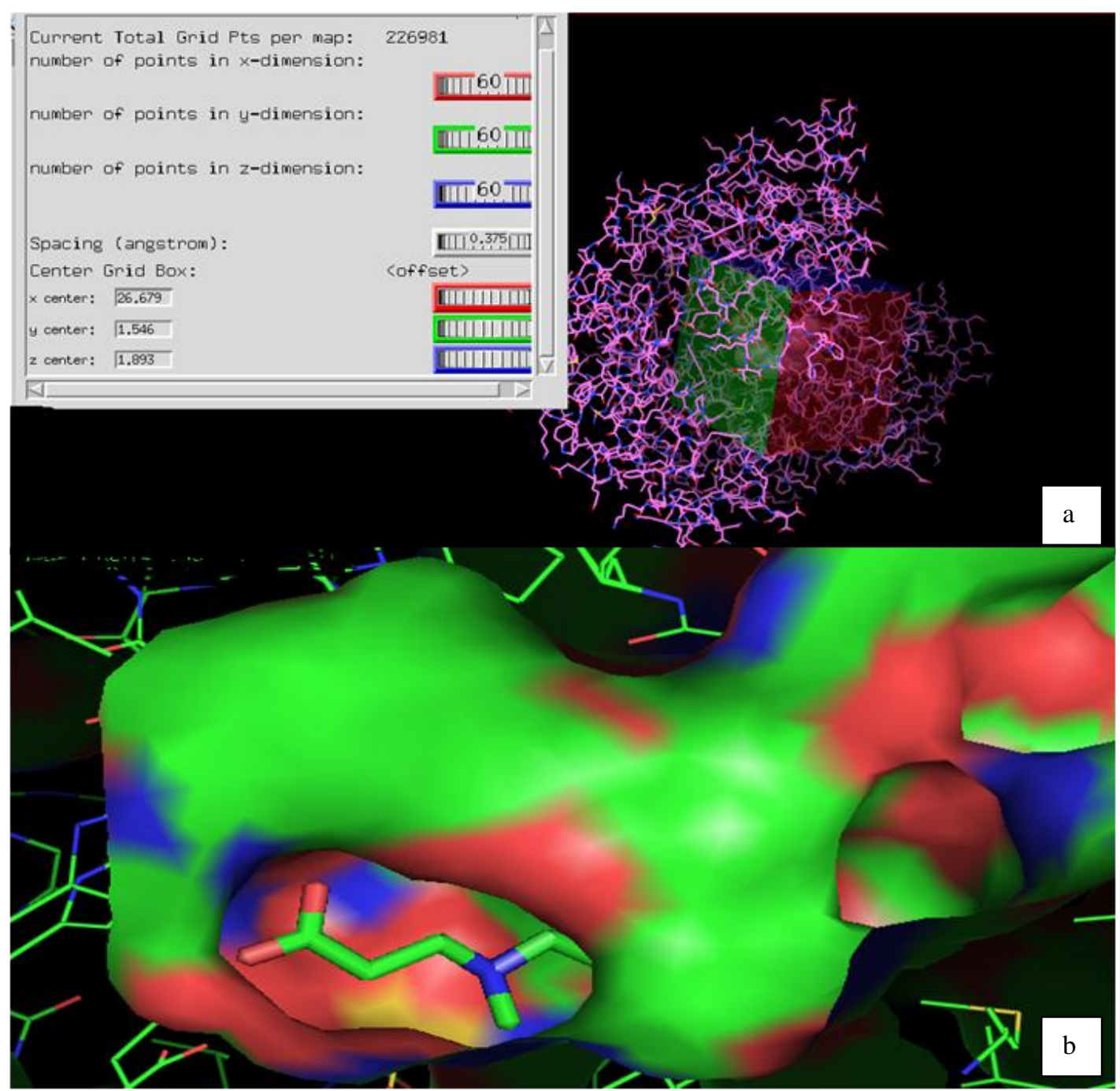

Gambar 2. Visualisasi 3D grid box dengan AutoDock Tools 1.5.6 (a) dan lubang kantung aktif protein Leukotrien A4 Hidrolase dengan program Pymol (b).

\section{Analisis Docking}

Hasil docking yang baik dapat dilihat dengan membandingkan nilai energi bebas Gibbs $(\Delta G)$, tetapan inhibisi, dan interaksi ikatan hidrogen antara ligan dan protein. Berdasarkan pada nilai $\Delta G$ tersebut menggunakan persamaan Gibbs maka akan diperoleh nilai tetapan inhibisi $(K i)$ (Morris et al., 1998).

$$
\begin{aligned}
& K=1 / K i \ldots \ldots \ldots \ldots \ldots \ldots \\
& \Delta G=-R T \operatorname{Ln} K \ldots \ldots \ldots \ldots \\
& \Delta G=-R T \operatorname{Ln} 1 / K i^{\cdots} \ldots \\
& \Delta G=R T \operatorname{Ln} K i \ldots \ldots \ldots \ldots . \\
& K i=e^{\frac{\Delta G}{R T}} \ldots \ldots \ldots \ldots \ldots .
\end{aligned}
$$

Tabel 1. Hasil simulasi docking protein Leukotrien A4 Hidrolase

\begin{tabular}{cccccc}
\hline Ligan & $\begin{array}{c}\text { Bobot } \\
\text { molekul } \\
(\mathrm{g} / \mathrm{mol})\end{array}$ & $\log \mathrm{P}$ & $\begin{array}{c}\text { Energi bebas } \\
\text { Gibbs }(\mathrm{kkal} / \mathrm{mol})\end{array}$ & $\begin{array}{c}\mathrm{Ki} \\
(\mu \mathrm{M})\end{array}$ & $\begin{array}{c}\text { Jumlah Ikatan } \\
\text { Hidrogen }\end{array}$ \\
\hline Bullatalisin & 638.48 & 6.70 & -11.30 & $5.15 \times 10^{-3}$ & 4 \\
Standar & 326.18 & 3.85 & -11.80 & $2.21 \times 10^{-3}$ & 2 \\
\hline
\end{tabular}


Ikatan pembentukan kompleks yang kuat ditandai dengan nilai $\Delta G$ yang rendah, tetapan inhibisi rendah, dan banyaknya jumlah interaksi ikatan hidrogen (Tambunan et al., 2010). Hasil simulasi docking dapat dilihat pada Tabel 1. Energi bebas Gibbs dan nilai konstanta inhibisi dari kompleks antara LTA4H-ligan Bullatalisin dan LTA4H-ligan standar berdasarkan pada hasil docking tampak tidak terlalu berbeda. Tanda negatif pada nilai energi bebas Gibbs serta nilai konstanta inhibisi yang semakin kecil, menunjukkan kompleks yang terbentuk antara ligan dan standar sangat kuat. Hal ini disebabkan oleh meningkatnya energi torsional dari kompleks tersebut sehingga membuat kompleks enzim dan ligan menjadi stabil (Tambunan et al., 2010).

Nilai energi bebas Gibbs tersebut merupakan kontribusi interaksi antara protein denganligan, interaksi tersebut terjadi secara intermolekul, yaitu Van der Waals atau ikatan hidrogen. Visualisasi interaksi antara protein dan ligan dapat dilhat dari interaksi elektrostatik dengan menggunakan Pymol (DeLano, 2002).Interaksi antara ligan dan protein diharapkan untuk mengganggu stabilitas dan kinerja enzim. Jarak interaksi ikatan yang dekat serta jumlah ikatan hidrogen yang terbentuk pada interaksi protein Leukotrien A4 Hidrolase-Bullatalisin lebih banyak dibandingkan dengan protein Leukotrien A4 Hidrolase-standar (Gambar 3).
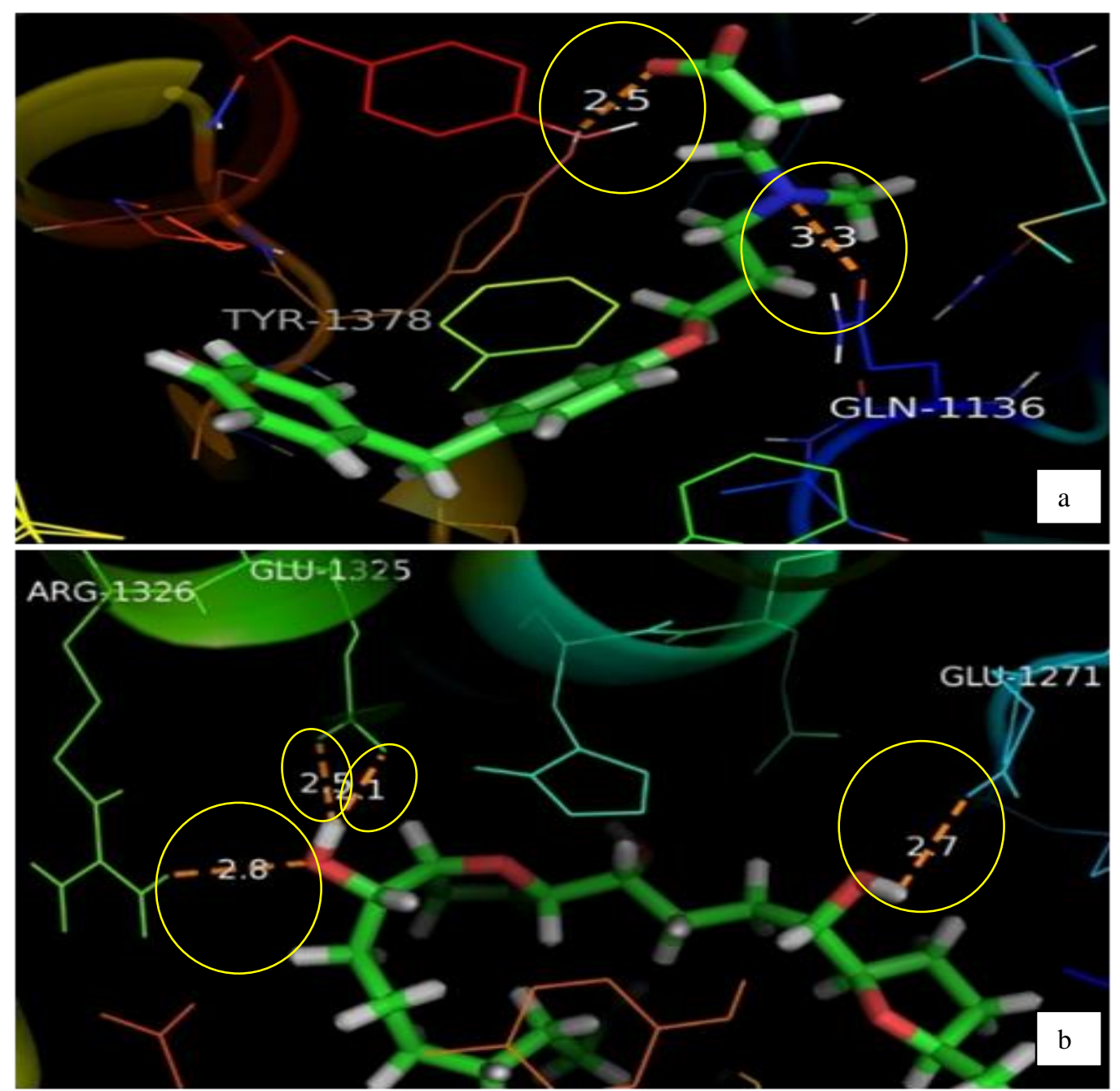

Gambar 3. Visualisasi 3 dimensi interaksi kontak residu ikatan antara protein Leukotrien A4 Hidrolase-liganstandar (a) dan ligan Bullatalisin (b) dengan program Pymol 
Tabel 2 menunjukkan kontak residu asam amino antara protein LTA4H dan ligan. Residu asam amino bercetak tebal merupakan asam amino penyusun kantung aktif dari protein LTA4H. Interaksi ikatan hidrogen dari ligan Bullatalisin terjadi pada asam

Tabel 2. Kontak residu asam amino protein Leukotrien A4 Hidrolase dan ligan

\begin{tabular}{ccc}
\hline Ligan & $\begin{array}{c}\text { Residu } \\
\text { Asam amino }\end{array}$ & $\begin{array}{c}\text { Jarak Interaksi } \\
(\AA)\end{array}$ \\
\hline Bullatalisin & Glu 271 & 2.7 \\
& Glu 325 & 2.1 \\
& Glu 325 & 2.5 \\
Standar & Arg 326 & 2.8 \\
& Gln 136 & 3.3 \\
& Tyr 378 & 2.5 \\
\hline
\end{tabular}

Evaluasi presisi hasil posisi docking antara protein dan ligan dilakukan dengan membandingkan nilai RMSD dari 2 metode program docking, yaitu AutoDockdan AutoDock Vina sebanyak 10 kali ulangan amino Glu 271, Glu 325, Arg 326, sedangkan kontak residu asam amino dengan standar terjadi pada asam amino Gln 136 dan Tyr 378. Interaksi antara ligan dengan asam amino kantung aktif tersebut diharapkan dapat menghambat kinerja protein LTA4H.

(Tabel 3). RMSD docking berdasarkan pada hasil superimpose dari setiap ulangan.

Nilai rerata RMSD pada hasil AutoDock Tools (ADT) lebih dari 2, hal ini menunjukkan perbedaan letak posisi docking ikatan antara kompleks ligan standar-protein dan ligan Bullatalisin-protein dalam setiap ulangan. Sedangkan pada AutoDock Vina memiliki nilai rerata RMSD mendekati satu, yang menunjukkan letak posisi docking diantara kedua kompleks ligan tidak terlalu berbeda (Purnomo, 2013). Nilai RMSD kurang dari $2 \AA$ menunjukkan presisi hasil konformasi docking yang baik (Santoyo et al., 2013).

Table 3. Hasil validasi docking ligan standar AutoDock Tools dan AutoDock Vina

\begin{tabular}{ccccccccccccc}
\hline \multicolumn{2}{c}{ Ulangan } & 1 & 2 & 3 & 4 & 5 & 6 & 7 & 8 & 9 & 10 & rerata \\
\hline $\begin{array}{c}\text { RMSD } \\
(\AA)\end{array}$ & Vina & 1.0459 & 1.0390 & 1.0464 & 1.0351 & 1.0340 & 1.0302 & 1.0465 & 1.0349 & 1.0432 & 1.0460 & 1.0401 \\
& ADT & 2.1952 & 2.5445 & 2.5408 & 2.8675 & 2.2064 & 2.4156 & 2.5663 & 2.5635 & 2.4920 & 2.1680 & 2.4560 \\
\hline
\end{tabular}

Tabel 4. Hasil uji F energi bebas Gibbs antara ligan standar dan bullatalisin

\begin{tabular}{|c|c|c|}
\hline \multirow{2}{*}{ Ulangan } & \multicolumn{2}{|c|}{$\Delta \mathrm{G}(\mathrm{kKal} / \mathrm{mol})$} \\
\hline & Standar & Bullatalisin \\
\hline 1 & -11.8 & -11.4 \\
\hline 2 & -11.8 & -11.3 \\
\hline 3 & -11.9 & -11.3 \\
\hline 4 & -11.8 & -11.3 \\
\hline 5 & -11.8 & -11.3 \\
\hline 6 & -11.8 & -11.4 \\
\hline 7 & -11.8 & -11.3 \\
\hline 8 & -11.8 & -11.3 \\
\hline 9 & -11.8 & -11.3 \\
\hline 10 & -11.8 & -11.4 \\
\hline rerata & -11.8 & -11.3 \\
\hline $\mathrm{Sd}$ & 0.0316 & 0.0483 \\
\hline Varians & 0.0010 & 0.0023 \\
\hline $\mathrm{F}_{\text {Hitung }}$ & \multicolumn{2}{|c|}{2.3333} \\
\hline Derajat Bebas & 9 & 9 \\
\hline $\mathrm{F}_{(0.05,9,9)}$ & \multicolumn{2}{|c|}{4.0260} \\
\hline
\end{tabular}

Berdasarkan pada hasil uji $\mathrm{F}$ didapatkan hasil bahwa tidak berbeda signifikan dari hasil nilai $\Delta \mathrm{G}$ antara standar dan Bullatalisin sebagai kandidat ligan hasil docking. Pada Uji signifikansi, juga dapat dilihat antara hasil docking standar dan ligan hasil docking tidak berbeda nyata. Hal ini menunjukkan bahwa antara standar dengan Bullatalisin menghasilkan nilai $\Delta \mathrm{G}$ tidak berbeda signifikan secara statistik (Tabel 4).

\section{SIMPULAN DAN SARAN Simpulan}

Berdasarkan pada hasil analisis parameterdocking, ligan Bullatalisin dan standar dapat menempati alternatif kantung aktif protein LTA4H. Interaksi ligan dengan residu asam amino penyusun kantung aktif diharapkan dapat mengganggu aktivitas protein. Energi bebas Gibbs $(\Delta G)$ kedua ligan tersebut tidak berbeda nyata secara statisitik uji $\mathrm{F}$. 


\section{Saran}

Pada penelitian selanjutnya perlu dilakukan modifikasi Bullatalisin, yang diharapkan bisa meningkatkan nilai energi bebas Gibbs, dan itu dapat menjadi obat jenis baru yanglebih baik dari standar. Selain itu perlu dilakukan analisis penentuan dari aktivitas proteinLTA4H terhadap inhibisi dari ligan obat.

\section{DAFTAR PUSTAKA}

Arguello, M., Paz, S., Hernandez, E., et al. 2006. Leukotriene A4 hydrolase expression in PEL cells is regulated at the transcriptional level and leads to increased leukotriene B4 production. J Immunol. 176:7051-7061.

Boyle, N.M.O., Banck, M., James, C.A., et al. 2011. Open Babel: An open chemical toolbox. J. Cheminf. 3:33.

Chen, X., Li, N., Wang, S., et al. 2003. Leukotriene A4 hydrolase in rat and human esophageal adenocarcinomas and inhibitory effects of bestatin. $J$ Natl Cancer Inst. 95:1053-1061.

Chen, X, Wang, S, Wu, N, Yang, C.S. 2004. Leukotriene A4 hydrolase as a target for cancer prevention and therapy. Current cancer Drug Target. 4:267283.

Chiu, H.F., Chih, T.T., Hsian, Y.M., Tseng, C.H., Wu, M.J., Wu, Y.C. 2003. Bullatacin, a potent antitumor Annonaceous acetogenin, induces apoptosis through a reduction of intracellular cAMP and cGMP levels in human hepatoma 2.2.15 cells. Biochem Pharmacol. 65(3):319-327.

Chul, H.J., Ann, M.B., Angelo, P., et al. 2009. [6]-Gingerol suppresses colon cancer growth by targeting leukotriene A4 hydrolase. Cancer Res. 69: 55845591.

DeLano, W.L. 2002. The PyMOL molecular graphics system. http://www.pymol.org.

Gilson, M.K., Zhou, H. X. 2007. Calculation of protein-ligand binding affinities.
Annual Review of Biophysics and Biomolecular Structure. 36:21-42.

Haeggström, J.Z., Funk, CD. 2011. Lipoxygenase and leukotriene pathways: Biochemistry, biology, and roles in disease. Chem Rev. 111(10):5866-5898.

Hevener, K., Zhao, W., Ball, D., Babaoglu, K., Qi, J.J., White, S., Lee, R. 2009. Validation of molecular docking programs for virtual screening against dihydropteroate synthase. $J$ of Chemical Information and Modeling. 46(2):444-460.

Idrees, S., Ashfaq, U.A. 2014. Discovery and design of cyclic peptides as dengue virus inhibitors through structurebased molecular docking.Asian Pacific Journal of Tropical Medicine. 7(7):513-516.

Liang, Y.J, Zhang, X, Dai, C.L., et al. 2009. Bullatacin Triggered ABCB1Overexpressing Cell Apoptosis via the Mitochondrial-Dependent Pathway. Journal of Biomedicine and Biotechnology. 2009, Article ID 867123:1-9.

Marjolein, M.G.M.T, Nordlund, P., Haeggström,J.Z. 2001.Crystal structure of human leukotriene $\mathrm{A}_{4}$ hydrolase, a bifunctional enzyme in inflammation. Nature Structural Biology. 8:131-135.

Morris, G.M., Goodsell, D.S., Halliday, R.S., Huey, R., Hart, W.E., Belew, R.K., Olson, A.J. 1998. Automated docking using a lamarckian genetic algorithm and an empirical binding free energy function. $J$ Comput Chem. 19(14):1639-1662.

Niegowski, D., Thunnissen, M., Tholander, F., Rinaldo-Matthis, A., Muroya, A., Haeggstrom, J.Z. 2102. Structure of human Leukotriene A4 hydrolase in complex with inhibitor sc57461A. http://www.rcsb.org/pdb/explore/expl ore.do? structureId=3U9W.

Okun, J.G., Lummen, P., Brandt, U. 1999. Three classes of inhibitors share a common binding domain in 
mitochondrial complex I (NADH:Ubiquinone oxidoreductase. The Journal of Biological Chemistry. 274(5):2625-2630.

Orning, L., Gierse, J.K, Fitzpatrick, F.A. 1994. The bifunctional enzyme leukotriene-A4 hydrolase is an arginine aminopeptidase of high efficiency and specificity. $J$ Biol Chem 269(15):11269-11273.

Purnomo, H. 2013. Kimia komputasi: molecular docking plants penambatan molekul plants [protein-ligand-antsystem] ("ilmu semut"). Pustaka Pelajar. Yogyakarta. 62-63.

Rester, U. 2008. From virtuality to reality virtual screening in lead discovery and lead optimization: a medicinal chemistry perspective. Current Opinion in Drug Discovery \& Development.11: 559-568.

Santoyo, A.H., Barajas, A.Y.T., Altuzar, V., et al. 2013. Protein-Protein and Protein-Ligand Docking. In Tech. 6481.

Seeliger, D., de Groot, B.L. 2010. Ligand docking and binding site analysis with PyMOL and AutoDock/Vina. $J$ Comput Aided Mol Des. 24:417-422.

Sousa, S.F, Fernandes, P.A., Ramos, M.J. 2006. Protein-ligand docking: current status and future challenges. Proteins. 65(1):15-26.

Stsiapanavaa, A., Olssona, U., Wana, M., et al. 2014. Binding of Pro-Gly-Pro at the active site of leukotriene A4 hydrolase/aminopeptidase and development of an epoxide hydrolase selective inhibitor. PNAS. 111(11):4227-4232.

Tambunan, U.S.F., Alamudi, S. 2010. Designing cyclic peptide inhibitor of dengue virus NS3-NS2B protease by using molecular docking approach. Bioinformation. 5(6):250-254.

Tholander, F., et al. 2008. Structure-based dissection of the active site chemistry of leukotriene A4 hydrolase: Implications for M1 aminopeptidases and inhibitor design. Chem Biol. 15(9):920-929.

Thunnissen, M.M., Nordlund, P., Haeggstrom, J.Z. 2001. Crystal structure of human leukotriene A4 hydrolase, a bifunc- tional enzyme in inflammation. Nat Struct Biol. 8:131135.

Trott, O., Olson, A. 2010. AutoDock Vina: improving the speed and accuracy of docking with a new scoring function, efficient optimization and multithreading. $J$ CompChem. 31:455-461.

Yu, H.H., Rupprecht, J.K.,, Anderson, J.E., et al.1989. Bullatalisin, a novel bioactive acetogenin from annona bullata (annonaceae). Terrohedron. 45(22):6941-6948. 